\title{
DIFFUSION OF CALCIUM CHLORIDE IN A MODIFIED BENTONITE: IMPACT ON OSMOTIC EFFICIENCY AND HYDRAULIC CONDUCTIVITY
}

\author{
Francesco Mazzieri $^{1}$ *, Gemmina Di Emidio ${ }^{2}$, and Peter O.Van Impe $^{2}$ \\ ${ }^{1}$ Department of FIMET, Università Politecnica delle Marche, Via Brecce Bianche 60131 Ancona, Italy \\ ${ }^{2}$ Laboratory of Geotechnics, Ghent University, TechnologiePark, 905, Zwijnaarde, Belgium
}

\begin{abstract}
Chemically modified bentonites are being developed with the aim of preserving low hydraulic conductivity in the presence of potentially aggressive permeants in pollutant-containment applications. 'Multiswellable' bentonite (MSB) has been obtained by treating standard sodium bentonite with propylene carbonate. Research on the engineering properties of MSB has focused mainly on permeability and chemical compatibility. Solute diffusion and membrane behavior in MSB have not yet been investigated. A combined chemico-osmotic/diffusion test was performed on a MSB specimen using a $5 \mathrm{mM} \mathrm{CaCl}_{2}$ solution. Permeability with distilled water and with the $5 \mathrm{mM} \mathrm{CaCl}_{2}$ solution was measured prior to and after the chemico-osmotic/diffusion tests. The material exhibited time-dependent membrane behavior with a peak osmotic efficiency value $(\omega)$ of 0.172 that gradually shifted to zero upon breakthrough of calcium ions. Effective diffusion coefficients of calcium and chloride ions were in the range commonly described for untreated bentonite at similar porosities. After the chemico-osmotic/diffusion stage and permeation with $5 \mathrm{mM} \mathrm{CaCl}_{2}$, the hydraulic conductivity of MSB increased from $1.1 \times 10^{-11} \mathrm{~m} / \mathrm{s}$ to $7.0 \times 10^{-11} \mathrm{~m} / \mathrm{s}$. The MSB was apparently converted into a calcium-exchanged bentonite at the end of the test. Prehydration and subsequent permeation might have contributed to elution of the organic additive from the clay. Further investigation is recommended to clarify the effect of prehydration on the hydraulic performance of MSB in the presence of potentially aggressive permeants.
\end{abstract}

Key Words-Chemico-osmotic Efficiency, Contaminant-resistant, Diffusion, Hydraulic Conductivity, Membrane, 'Multiswellable' Bentonite, Propylene Carbonate, Swelling.

\section{INTRODUCTION}

Bentonite has been used widely in engineered barriers for pollutant containment (e.g. soil-bentonite mixtures, cement-bentonite mixtures). Geosynthetic Clay Liners (GCLs) consisting of a thin layer of bentonite sandwiched between two geotextiles or glued to a geomembrane are increasingly used as hydraulic barriers in landfill covers and liners. The GCLs that do not include a geomembrane have hydraulic conductivity on the order of $10^{-11} \mathrm{~m} / \mathrm{s}$ when permeated with deionized water or dilute aqueous solutions, owing to the low permeability properties of Na-montmorillonite, the main component of common bentonites (Bouazza, 2002). Unfortunately, the hydraulic conductivity of GCLs can be increased drastically by inorganic permeants that are aggressive to Na-montmorillonite, e.g. solutions with high concentrations and/or containing predominantly multivalent cations (Jo et al., 2004).

Several types of contaminant-resistant bentonites have been developed with the aim of preserving low hydraulic conductivity in the presence of potentially aggressive permeants (Onikata et al., 1996; Lo et al., 1997; Ashmawy et al., 2002). This paper presents test

\footnotetext{
* E-mail address of corresponding author:
} f.mazzieri@univpm.it

DOI: $10.1346 /$ CCMN.2010.0580306 results for MultiSwellable Bentonite (MSB), a chemically modified bentonite (Onikata et al., 1999). Previous research on the engineering properties of MSB has focused mainly on permeability and chemical compatibility (Katsumi et al., 2001; Mazzieri and Pasqualini, 2006; Katsumi et al., 2008). In low-permeability barriers, diffusion may become the dominant pollutanttransport mechanism (Shackelford and Daniel, 1991). To the authors' knowledge, solute diffusion in MSB has not yet been investigated. A combined chemico-osmotic/ diffusion test was, therefore, performed on MSB using a $5 \mathrm{mM} \mathrm{CaCl} 2$ solution. The primary purpose was to gather information on the diffusion of solutes in MSB. Secondly, the chemico-osmotic coefficient, $\omega$, of MSB in the presence of the electrolyte solution was measured during the diffusion test. The purpose was to evaluate the ability of MSB to sustain membrane behavior and to compare the results with literature data on untreated bentonite. Finally, the impact of diffusion and subsequent permeation with $5 \mathrm{mM} \mathrm{CaCl} \mathrm{Ca}_{2}$ on the hydraulic conductivity of MSB was evaluated.

\section{PERMEABILITY AND MEMBRANE BEHAVIOR OF BENTONITES}

The efficiency of bentonite as a component of hydraulic barriers is attributed to the large swelling capacity and low permeability of Na-montmorillonite. Swelling of montmorillonite from a dry state occurs in 
two phases: the limited crystalline and the extensive crystalline (Quirk and Marčelja, 1997) or osmotic (Onikata et al., 1999; Jo et al., 2004) phases. In the former phase, water is absorbed as a result of the hydration of interlayer cations and solid surfaces until several monolayers of water molecules are bound in the interlayer. The latter phase consists of the macroscopic expansion of the clay volume as a result of further water adsorption in the interlayer space.

The extensive crystalline swelling is attributed to the interaction of diffuse double layers of contiguous clay surfaces, and the repulsive pressure acting between them can be modeled as the osmotic pressure difference between the center of the interlayer space and the bulk fluid (e.g. Bolt, 1956). Other authors have discounted the influence of double-layer interactions and attributed the extensive crystalline swelling to the structural perturbation of the interfacial water under the influence of the clays surface (e.g. Viani et al., 1983).

For Na-montmorillonite, the osmotic phase of swelling is identified with $d_{001}$ spacings reaching values $>1.9$ $\mathrm{nm}$ and it occurs if the hydrating liquid is pure water or a dilute solution, whereas it is prevented by electrolyte concentrations of $>0.3 \mathrm{M} \mathrm{NaCl}$ (Norrish and Quirk, 1954). If multivalent cations (e.g. $\mathrm{Ca}^{2+}, \mathrm{Mg}^{2+}, \mathrm{Al}^{3+}$ ) predominantly occupy the exchange complex, swelling is limited to the crystalline phase $\left(d_{001} \leqslant 1.9 \mathrm{~nm}\right)$ even if the hydrating solution is pure water. In montmorillonites that undergo both crystalline and extensive swelling, a large number of water molecules is bound (hydraulically immobile). As a result, the fraction of the pore space occupied by bulk water that is free to flow is relatively small and the flow paths are tortuous and elongated. The clay has a dispersed structure in which clay particles are partly present as separated platelets and the hydraulic conductivity to water is typically very low (Mesri and Olson, 1971; Mitchell, 1993; Jo et al., 2001, 2004).

Na-montmorillonite-rich clayey soils (e.g. bentonites) have been shown to behave as membranes, i.e. restrict the transport of solutes while a flow of water (chemical osmosis) is induced in the direction opposite to that of the chemical gradient (e.g. Katchalsky and Curran, 1965). The extent to which clays behave as semipermeable membranes has traditionally been quantified in terms of the osmotic efficiency coefficient $\omega$ (Mitchell, 1993). The membrane behavior of bentonite is being regarded with great interest in view of the beneficial impact on containment capability, since a barrier exhibiting chemical osmosis will generally perform better in terms of solute containment than a barrier where chemical osmosis is absent (Kejzer et al., 1999; Malusis and Shackelford, 2002).

In the case of charged solutes, membrane behavior is generally attributed to electrostatic repulsion of the ions by electric fields generated by the overlapping diffuse double layers of closely spaced clay particles (Fritz,
1986). The restriction of solute transport by clayey soils is usually partial, so that the soil behaves like a 'leaky' or semi-permeable membrane allowing some flux of solutes. Hence, the chemico-osmotic behavior may be altered by the invasion (e.g. by molecular diffusion) of the pore space by solutes that cause compression of double layers, e.g. multivalent ions and/or high electrolyte concentrations (Mazzieri et al., 2003; Shackelford and Lee, 2003). The same factors usually increase the hydraulic conductivity of common bentonites.

The MSB is a modified bentonite obtained by treating standard sodium bentonite with propylene carbonate (PC below), an aprotic polar organic solvent. Onikata et al. (1999) showed that PC forms complexes with homoionic montmorillonite by intercalation, and that the PC-montmorillonite complexes exhibit osmotic swelling (basal spacing $d_{001}>1.9 \mathrm{~nm}$ ) in electrolyte solutions up to $0.75 \mathrm{M} \mathrm{NaCl}$, whereas untreated bentonite exhibits osmotic swelling for $\mathrm{NaCl}$ concentrations of $<0.3 \mathrm{M}$. The activating effect of $\mathrm{PC}$ on osmotic swelling has been explained in terms of solvent electron donor and acceptor properties (Onikata et al., 2000). Treatment with PC not only improves the swelling properties but also the hydraulic conductivity of MSB. For example, permeability tests revealed that MSB had a hydraulic conductivity of $2.0 \times 10^{-11}$ with $1 \mathrm{M} \mathrm{NaCl}$ whereas untreated bentonite had a hydraulic conductivity of $2.3 \times 10^{-10} \mathrm{~m} / \mathrm{s}$ (Katsumi et al., 2008). Verifying whether modified bentonites such as MSB can sustain any membrane behavior is of great interest for containment applications (Shackelford, 2005).

\section{MATERIALS AND METHODS}

\section{Materials}

The MSB used in this study consisted of $80 \% \mathrm{Na}-$ bentonite (NB hereafter) and 20\% PC on a dry weight basis (i.e. the $\mathrm{PC}$ to $\mathrm{NB}$ weight ratio $=0.25$ ). The MSB and NB were supplied to the authors by the producer (Hojun Kogyo Corp., Annaka, Gunma, Japan). The main physical and chemical properties of the clays were derived partly from the product information sheets and partly by standard soil-analysis procedures (see the Results section below).

Powder X-ray diffraction (XRD) analyses were performed on air-dried samples of MSB and NB using a Philips diffractometer (PW1730 X-ray generator, PW $1050 / 70$ goniometer and $\mathrm{CuK} \alpha$ radiation). No pretreatment of the clays was performed as the main purpose of the XRD analysis was to compare diffraction patterns and to observe the differences induced by the organic additive.

The liquids used in the study were distilled water (hereafter DW) and a $5 \mathrm{mM}$ solution of $\mathrm{CaCl}_{2}$. The type and concentration of the solution were selected in order to allow comparison with results of a similar test on untreated Na-bentonite (Shackelford and Lee, 2003). 
Distilled water $(\mathrm{pH}=5.8$, Electrical Conductivity, $E C$, = $1.7 \mathrm{mS} / \mathrm{m}$ ) was produced using a water-distilling apparatus DZ 8103, Schott. The $5 \mathrm{mM} \mathrm{CaCl}_{2}$ solution $(\mathrm{pH}=5.7, E C=113 \mathrm{mS} / \mathrm{m})$ was prepared by dissolving analytical-grade $\mathrm{CaCl}_{2} \cdot 2 \mathrm{H}_{2} \mathrm{O}$ (>99.9\% Merck, Belgium) in DW.

\section{Free swell tests}

Free swell tests (ASTM D5890) were performed to examine the swelling behavior of MSB in the testing liquids ( $\mathrm{DW}$ and $5 \mathrm{mM} \mathrm{CaCl}_{2}$ ). Two grams of oven-dried clay were dusted carefully into a graduated cylinder containing the solution and the volume occupied by the clay ('free swell') was recorded after $24 \mathrm{~h}$. Preliminary tests had shown some differences in the free swell results performed on air-dried or oven-dried MSB samples. In particular, the free swell was found to decrease significantly for oven-dried MSB compared to air-dried MSB. Heating at $105^{\circ} \mathrm{C}$ probably evaporated some of the weakly bound PC (Onikata et al., 1999). Hence, MSB specimens to be used for further testing were not ovendried. In order to estimate the gravimetric water content, separate portions of MSB were oven-dried at $105^{\circ} \mathrm{C}$ for $24 \mathrm{~h}$. Although some of the recorded mass loss after oven drying might have been caused by evaporation of PC, no correction was adopted and the recorded mass loss was attributed entirely to water.

\section{Chemico-osmotic/diffusion test}

The combined chemico-osmotic/diffusion test was carried out by means of the testing apparatus described by Mazzieri et al. (2003), consisting essentially of the test cell and the pumping system (Figure 1). The cell consisted of a lower mold and a pressure chamber separated by a rigid piston. The clay specimen was housed in the lower mold and confined between two porous plates. Swelling of the clay during the test was prevented by blocking the top piston.

The MSB specimen was prepared with a view to simulating thin bentonitic barriers like Geosynthetic Clay Liners. A thin layer of dry MSB was spread into the lower mold of the testing cell. The amount of bentonite used $\left(0.45 \mathrm{~g}\right.$ dry solids $\left./ \mathrm{cm}^{2}\right)$ was similar to that of commercial GCLs. The mold was subsequently inundated with DW and the specimen was allowed to swell unconfined to a height of $\sim 10 \mathrm{~mm}$. The swollen MSB was then consolidated to the desired height of $7.4 \mathrm{~mm}$ (corresponding to a porosity of 0.717 ) by pressurizing the chamber above the top piston. The specimen was then permeated with DW to remove soluble salts, improve saturation, and measure the reference hydraulic conductivity.

After permeation, the chemico-osmotic/diffusion stage of the experiment commenced. A chemical gradient was induced across the specimens by circulating solutions of different concentrations at the specimen boundaries (i.e. the porous plates). The solutions were pumped at the same volumetric rate, $q\left(4.2 \times 10^{-7} \mathrm{~L} \mathrm{~s}^{-1}\right.$ in the present experiment). At the top boundary, the solution was infused at concentration $C_{\mathrm{t}, \mathrm{i}}(=5 \mathrm{mM}$ $\mathrm{CaCl}_{2}$ ) and withdrawn at concentration $C_{\mathrm{t}, \mathrm{o}}<C_{\mathrm{t}, \mathrm{i}}$ as a result of the diffusion of solutes $\left(\mathrm{Ca}^{2+}\right.$ and $\left.\mathrm{Cl}^{-}\right)$into the clay. At the base boundary, the solution was infused at concentration $C_{\mathrm{b}, \mathrm{i}}\left(\mathrm{DW}\right.$ in this experiment, $C_{\mathrm{b}, \mathrm{i}}=0$ ) and withdrawn at concentration $C_{\mathrm{b}, \mathrm{o}}>C_{\mathrm{b}, \mathrm{i}}$ as a result of solute diffusion from the clay. The outflow concentra-

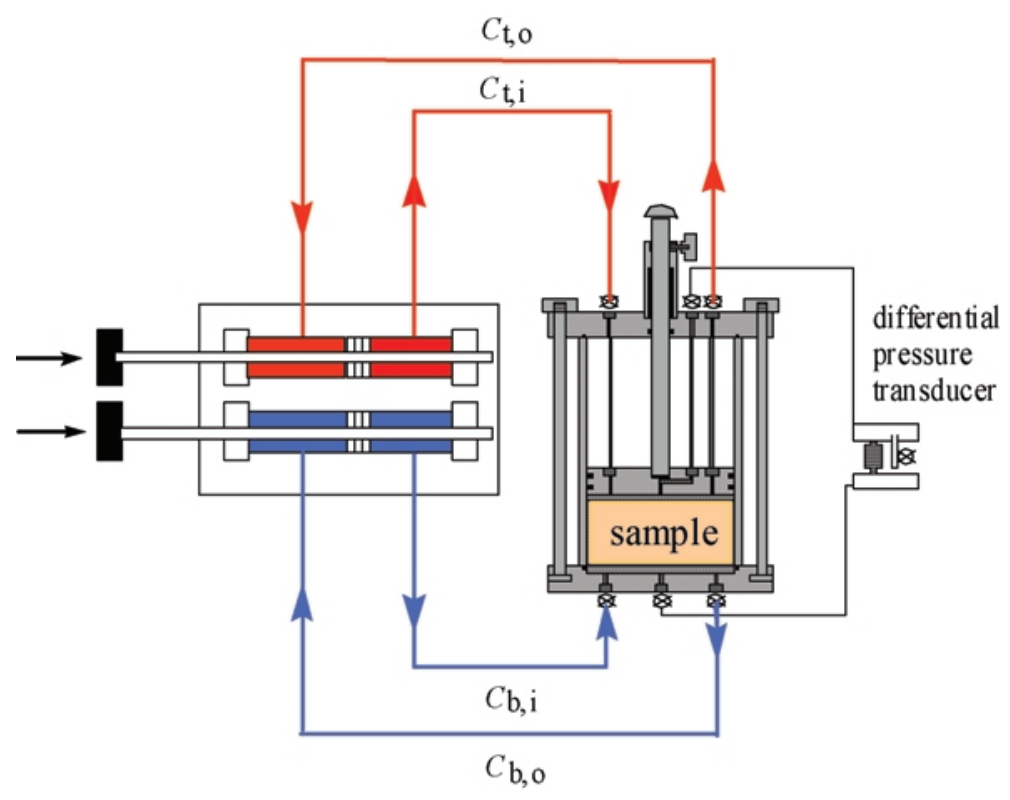

Figure 1. Schematic view of the testing apparatus. Arrows indicate circulation flow directions (modified after Mazzieri et al., 2003). 
tions, $C_{\mathrm{t}, \mathrm{o}}$ and $C_{\mathrm{b}, \mathrm{o}}$, were monitored in order to evaluate the solute-mass flux across the specimen. Cation and anion concentrations in the outflow solutions were measured using a Varian SpectrAA 600 spectrophotometer.

As no water could leave or enter the clay, no fluid flow occurred across the clay; in the presence of osmotic behavior, a differential pressure arose that was measured by means of the differential pressure transducer (Figure 1). The osmotic efficiency coefficient $\omega[-]$ is defined as follows (Malusis et al. 2001):

$$
\omega=\frac{\Delta P}{\Delta \pi}
$$

where $\Delta P=$ the measured differential pressure $[\mathrm{kPa}]$ and $\Delta \pi=$ the theoretical osmotic pressure difference across an ideal semi-permeabile membrane $[\mathrm{kPa}]$. For the strong electrolyte (i.e. completely dissociated) solution used in the present study, the theoretical osmotic pressure difference can be expressed in accordance with the van't Hoff equation as:

$$
\Delta \pi=v \mathrm{R} T \Delta C
$$

where $v=$ the number of ions per salt molecule, $\mathrm{R}=$ the universal gas constant $\left[8.314 \mathrm{~J} \mathrm{~mol}^{-1} \mathrm{~K}^{-1}\right], T=$ the absolute temperature $[\mathrm{K}], \Delta C=$ the salt concentration difference $\left[\mathrm{mol} \mathrm{L}^{-1}\right]$.

At the beginning of the experiment, DW was first circulated for 1 day at both ends of the specimen to establish a reference differential pressure and remove residual salts from the porous plates. The $5 \mathrm{mM} \mathrm{CaCl}_{2}$ solution was then circulated at the top end of the specimen until the steady states of the differential pressure and the diffusive flux were reached. Finally, permeation with $5 \mathrm{mM} \mathrm{CaCl}_{2}$ was carried out in order to assess the impact of the solution on the hydraulic conductivity of MSB.

\section{Test interpretation}

During chemico/osmotic-diffusion experiments, solute diffusion usually displays a transient phase, with variable $C_{\mathrm{t}, \mathrm{o}}$ and $C_{\mathrm{b}, \mathrm{o}}$, and a steady-state phase, with constant $C_{\mathrm{t}, \mathrm{o}}$ and $C_{\mathrm{b}, \mathrm{o}}$. To evaluate the solute-diffusion coefficient by the steady-state approach, the cumulative mass per unit area, $Q_{\mathrm{t}}\left[\mathrm{mol} \mathrm{m}{ }^{-2}\right]$, of a given solute was calculated as (Malusis et al., 2001):

$$
Q_{\mathrm{t}}=\frac{1}{A} \sum_{k=1}^{N} \Delta V_{k}\left(c_{\mathrm{b}, \mathrm{o}}\right)_{k}
$$

where $\Delta m_{k}=$ the mass increment [mol] in the $k^{\text {th }}$ sample collected over a given time interval $\Delta t, \Delta V_{k}=$ the outflow volume for the $k^{\text {th }}$ sample [L], $\left(c_{\mathrm{b}, \mathrm{o}}\right)_{k}=$ the outflow base solute concentration measured in the $k^{\text {th }}$ sample, and $N=$ the total number of samples collected. The $Q_{\mathrm{t}}$ vs. $t$ plot usually presents a curved portion (transient diffusion) and a linear portion (steady-state diffusion). The extrapolated intersection of the linear portion with the time axis is referred to as 'time-lag,' $t_{\mathrm{L}}$, whereas the intersection of the curved transient portion with the linear portion corresponds to the steady-state diffusive flux and is denoted as $t_{\mathrm{ss}}$. The slope of $Q_{\mathrm{t}} v s . t$ plot at steady state is related to the diffusive mass flux $J$ by:

$$
J=\frac{\Delta Q_{\mathrm{t}}}{\Delta t}
$$

At steady state, Fick's first law of diffusion in soils (Crank, 1975) gives:

$$
J=n D \frac{\left(\bar{C}_{\mathrm{t}}-\bar{C}_{\mathrm{b}}\right)}{H}
$$

where $J=$ the steady-state diffusive mass flux $\left[\mathrm{mol} \mathrm{m} \mathrm{m}^{-2} \mathrm{~s}^{-1}\right], \bar{C}_{\mathrm{t}}=$ the average solute concentration in the top plate $\left[\mathrm{mol} \mathrm{L}{ }^{-1}\right], \bar{C}_{\mathrm{b}}=$ the average solute concentration in the base plate $\left[\mathrm{mol} \mathrm{L}^{-1}\right], D=$ the bulk solute diffusion coefficient $\left[\mathrm{m}^{2} \mathrm{~s}^{1}\right], H=$ the specimen thickness [m], and $n=$ the total clay porosity [-]. The bulk diffusion coefficient, $D\left[\mathrm{~m}^{2} \mathrm{~s}^{-1}\right]$, is defined as follows (Manassero and Dominijanni, 2003):

$$
D=(1-\omega) \tau D_{0}
$$

where $\tau=$ the geometric tortuosity factor $(-)$ and $D_{0}=$ the solute free diffusion coefficient $\left[\mathrm{m}^{2} \mathrm{~s}^{-1}\right]$. Assuming that sorption of the solute on the clay can be represented by a linear isotherm, $t_{\mathrm{L}}$ is related to the retardation factor $\mathrm{R}_{\mathrm{d}}[-]$ as follows (Crank, 1975):

$$
R_{\mathrm{d}}=\frac{6 D t_{\mathrm{L}}}{H^{2}}
$$

Note that equation 7 derives from a closed-form solution to Fick's second law of diffusion in soils for a neutral solute undergoing linear sorption, for perfect flushing boundary conditions and an initial zero solute concentration across the clay. In the case of a binary electrolyte, the cation of which undergoes exchange by the clay, the rigorous transport model that accounts for linear sorption, the osmotic effect, and the constraint of electroneutrality consists of a coupled system of nonlinear partial differential equations that must be solved numerically (Malusis and Shackleford, 2002). Application of equation 7 to the transient transport of individual ions of a binary electrolyte results in a 'lumped' retardation factor that includes solute restriction, sorption, and electrical interaction between ions (Van Impe et al., 2005).

\section{RESULTS AND DISCUSSION}

\section{Materials characterization}

The untreated NB had a similar cation exchange capacity (CEC), cation occupancy, and free swell 
Table 1. Physical and chemical properties of the MSB and NB bentonites.

\begin{tabular}{|c|c|c|c|}
\hline \multirow{2}{*}{$\frac{\text { Property }}{\text { Product name }}$} & Source/method & \multicolumn{2}{|c|}{$\longrightarrow$ Value $\longrightarrow$} \\
\hline & Information sheet & Multigel@ (MSB) & Superclay $\mathbb{R}(\mathrm{NB})$ \\
\hline Principal mineral & Information sheet & Montmorillonite & Montmorillonite \\
\hline Water content $(\%)$ & ASTM D4959 & 21 & 10 \\
\hline Specific gravity, $G_{\mathrm{s}}(-)$ & ASTM D 854 & 2.15 & 2.63 \\
\hline Liquid limit ( $\%)$ & ASTM D4318 & 554 & 683 \\
\hline Clay $\mathrm{pH}$ & a & 7.0 & 9.0 \\
\hline Electrical conductivity $(\mathrm{mS} / \mathrm{m})$ & a & 18.8 & 15.3 \\
\hline Cation exchange capacity (meq/100 g) & - & $52.6^{\mathrm{b}}$ & $72.3^{\mathrm{c}}$ \\
\hline \multicolumn{4}{|l|}{ Exchangeable cations $(\mathrm{meq} / 100 \mathrm{~g})$} \\
\hline $\mathrm{Na}^{+}$ & & $41.0^{\mathrm{b}}$ & $45.4^{\mathrm{c}}$ \\
\hline $\mathrm{Ca}^{2+}$ & - & $16.9^{\mathrm{b}}$ & $19.1^{\mathrm{c}}$ \\
\hline $\mathrm{Mg}^{2+}$ & & $6.8^{\mathrm{b}}$ & $9.6^{\mathrm{c}}$ \\
\hline $\mathrm{K}^{+}$ & & $0.8^{\mathrm{b}}$ & $1.0^{\mathrm{c}}$ \\
\hline Soluble cations (meq/100 g): & d & & \\
\hline $\mathrm{Na}^{+}$ & & 13.5 & 2.0 \\
\hline $\mathrm{Ca}^{2+}$ & & 1.7 & 0.4 \\
\hline $\mathrm{Mg}^{2+}$ & & 0.8 & 0.8 \\
\hline $\mathrm{K}^{+}$ & & 0.6 & 0.8 \\
\hline Free swelling $(\mathrm{mL})$ & ASTM D5890 & 23 & 22 \\
\hline
\end{tabular}

\footnotetext{
${ }^{\mathrm{a}}$ Measured on a 1:50 bentonite-water extract.

$\mathrm{b}$ Based on the method of Sumner and Miller (1996).

${ }^{c}$ Data from Mishra et al. (2006).

${ }^{d}$ Based on the method after Rhoades (1996)
}

(Table 1) to bentonites used in commercial GCLs, particularly to those that have proven to behave as semi-permeable membranes (Malusis and Shackelford, 2001; Shackelford and Lee, 2003). NB was, therefore, assumed to exhibit chemico-osmotic behavior under suitable conditions (i.e. small salt concentrations, small thickness).

The specific gravity of MSB (2.15) as per ASTM D 854 was significantly smaller than that of untreated NB (2.63), which was consistent with the binding of PC molecules in the interlayer of montmorillonite (Kolstad et al., 2004). The exchangeable cations of MSB, previously washed with DW, were displaced with an ammonium acetate solution, following the procedure indicated by Sumner and Miller (1996). Sodium was the dominant cation, with a significant calcium content, analogous to NB. The sum of exchangeable cations exceeded the CEC, probably as a result of incomplete removal of soluble salts during washing with DW. Hence, the exchangeable cation concentrations may include a fraction of soluble cations.

The main feature of the XRD patterns (Figure 2) was the shift in the $d_{001}$ basal spacing of the MSB $\left(d_{001}=\right.$ $1.78 \mathrm{~nm})$ compared to $\mathrm{NB}\left(d_{001}=1.23 \mathrm{~nm}\right)$, reflecting

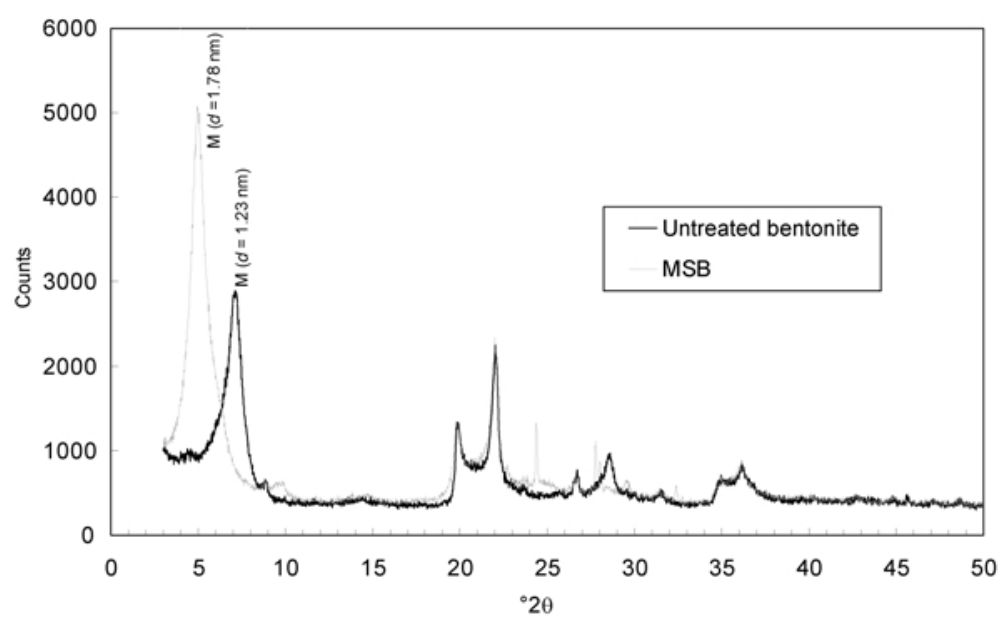

Figure 2. XRD patterns of MSB bentonite and NB bentonite. 
the presence of PC molecules coordinated with exchangeable cations in the interlayers.

Onikata et al. (1999) presented the basal spacings of air-dried homo-ionic montmorillonites mixed with various concentrations of PC. The basal spacing of homoionic $\mathrm{Na}, \mathrm{Ca}$, and $\mathrm{Mg}$ montmorillonites mixed with $25 \%$ PC was $1.9 \mathrm{~nm}$, suggesting the formation of bi-layers of PC between the silicate layers, whereas the $d_{001}$ spacing for K-montmorillonite was $1.4 \mathrm{~nm}$ with a mono-layer of PC molecules being formed. The $d_{001}$ spacing of air-dried MSB observed in this study $(1.78 \mathrm{~nm})$ was intermediate between the values observed for bi- and mono-layers of PC molecules, probably as a result of mixed cation occupation and/or slightly different residual water contents after air-drying.

\section{Free swell}

In an attempt to simulate the sequence of exposure of the chemico-osmotic/diffusion test, the same MSB was used for the free swell tests in DW and in $5 \mathrm{mM} \mathrm{CaCl}_{2}$. After completion of the test in DW, the bentonite was recovered, air-dried, and reused for the test with $5 \mathrm{mM}$ $\mathrm{CaCl}_{2}$. The free swell of MSB in DW was $23 \mathrm{~mL}$ whereas in $5 \mathrm{mM} \mathrm{CaCl}_{2}$ the free swell was $50 \mathrm{~mL}$. The base NB bentonite gave $22 \mathrm{~mL}$ in $\mathrm{DW}$ and $27 \mathrm{~mL}$ in $5 \mathrm{mM} \mathrm{CaCl}_{2}$. Onikata et al. (2000) attributed the swelling of MSB in electrolyte solutions to the formation of thick electrical double layers consisting of PC and water that coordinate with the interlayer cations between the silicate layers. The MSB swollen in $5 \mathrm{mM} \mathrm{CaCl}_{2}$ formed large flocs that did not remold completely when settled, which may partly explain the large swell volume. Moreover, the surpernatant was relatively clear whereas it was rather turbid with DW, reflecting the tendency of the clay particles to remain suspended. The same trend of increasing swell with $5 \mathrm{mM} \mathrm{CaCl}{ }_{2}$ compared to DW and the tendency to form flocs was also observed in NB, albeit to a much lesser extent.
Katsumi et al. (2008) reported results of free swell tests on $\mathrm{MSB}$ in $\mathrm{DW}$ and in $\mathrm{CaCl}_{2}$ solutions for concentrations ranging from $0.1 \mathrm{M}$ to $0.5 \mathrm{M}$. They found that the free swell of MSB in $\mathrm{CaCl}_{2}$ solutions was always less than in DW, but they reported no data for concentrations of $<0.1 \mathrm{M}$. Katsumi et al. (2008) also found that free swell results did not always correlate well with other properties of MSB. For example, they observed that the free swell of MSB increased from $28 \mathrm{~mL}$ in $\mathrm{DW}$ to $40 \mathrm{~mL}$ in $0.5 \mathrm{M} \mathrm{NaCl}$, but the Liquid Limit decreased from $500 \%$ in DW to $320 \%$ in $0.5 \mathrm{M}$ $\mathrm{NaCl}$. The hydraulic conductivity remained substantially unaltered, varying from $1.0 \times 10^{-11} \mathrm{~m} / \mathrm{s}$ in $\mathrm{DW}$ to $1.3 \times 10^{-11} \mathrm{~m} / \mathrm{s}$ in $0.5 \mathrm{M} \mathrm{NaCl}$. As a consequence, a considerable increase in the swelling power of MSB in a given liquid does not necessarily reflect a substantial improvement in terms of hydraulic conductivity.

\section{Permeation with DW}

Permeation with DW was continued until the Electrical Conductivity $(E C)$ of the effluent solution (Figure 3) was significantly less than the $E C$ of the 5 $\mathrm{mM} \mathrm{CaCl}{ }_{2}$ solution $(113 \mathrm{mS} / \mathrm{m})$. The $E C$ of the effluent was initially approximately double the $E C$ of the $5 \mathrm{mM}$ $\mathrm{CaCl}_{2}$ solution. The final $E C$ of effluent was $25 \mathrm{mS} / \mathrm{m}$, less than one-fourth of the source solution. The hydraulic conductivity $(k)$ of the specimen (Figure 3 ) was calculated from the measured effluent volume during permeation and the applied gradient in accordance with Darcy's Law. A relatively large hydraulic gradient $(\approx 770)$ was used in order to shorten the flushing stage, which still lasted $\sim 90$ days. The calculated $k$ of the MSB specimen with DW was relatively constant at $\approx 1.1 \times 10^{-11} \mathrm{~m} / \mathrm{s}$.

\section{Chemico-osmotic efficiency}

In the chemico-osmotic/diffusion stage of the test, the differential pressure across the MSB specimen was

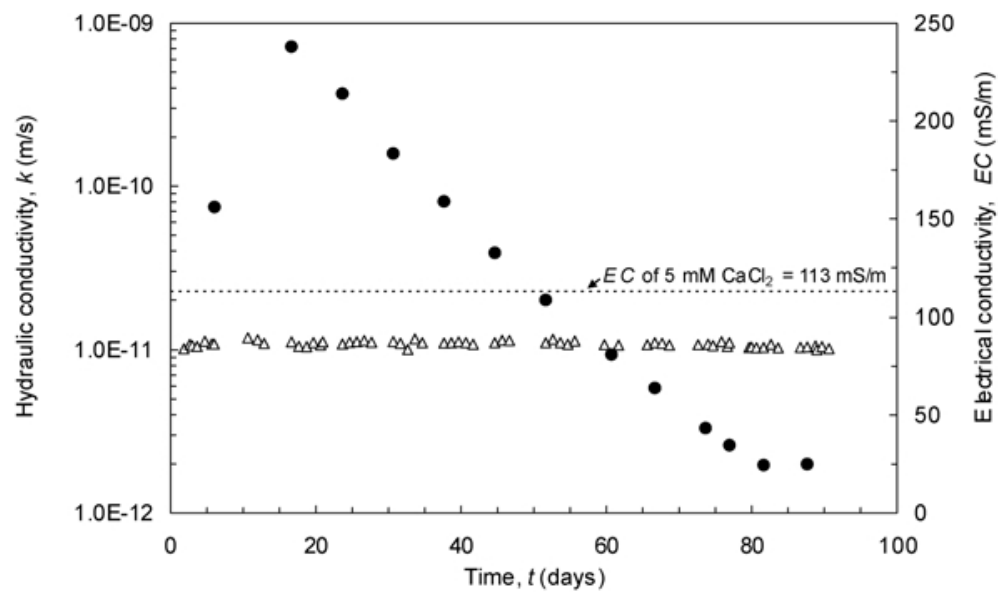

Figure 3. Hydraulic conductivity of MSB specimen permeated with distilled water, and electrical conductivity of the effluent. 
monitored with time (Figure 4). The hydraulic pressure and the osmotic pressure decreased with increasing vertical distance (positive $\mathrm{x}$ ) from the top boundary of the specimen; hence $-\Delta P$ was plotted. During circulation of DW, a non-zero average differential pressure $(-\Delta P)_{0} \approx 1.0 \mathrm{kPa}$ was measured, probably as a result of slightly different hydraulic conductivities of the porous plates (Malusis et al., 2001) and/or different residual salt content.

Replacement of DW with the $5 \mathrm{mM} \mathrm{CaCl}_{2}$ solution caused an immediate increase in the differential pressure to a peak value $(-\Delta P)_{\max }=7.3 \mathrm{kPa}$. The peak value occurred within $\sim 16 \mathrm{~h}$ of the circulation with the source solution. The differential pressure dropped gradually thereafter to values fluctuating around $(-\Delta P)_{0}$. Considering the scatter of the measurements, evaluating the steady state of the differential pressure exactly was difficult. Somewhat arbitrarily the steady state of $-\Delta P$ was assumed to have been achieved when the $-\Delta P$ vs. time curve first crossed the line representing $(-\Delta P)_{0}$, i.e. after $\sim 22$ days of circulation with the solution. The osmotic efficiency was calculated using equation 1 . The steady-state osmotic efficiency was $\omega_{\mathrm{ss}}=0$. The peak osmotic efficiency, $\omega_{\max }$, was calculated from equation 1 using $\Delta P=-6.3 \mathrm{kPa}$ and $\Delta \pi=-36.6 \mathrm{kPa}$, which is the maximum theoretical osmotic pressure difference calculated from the van't Hoff equation (equation 2) for $\Delta C=$ $-5 \mathrm{mM}, v=3$, and $T=293.15 \mathrm{~K}$. The maximum osmotic efficiency coefficient was $\omega_{\max }=0.172$. Therefore, the MSB specimen initially exhibited membrane behavior $(\omega>0)$, which was gradually destroyed $(\omega=0)$ during the test.

\section{Solute diffusion}

The impact of solute diffusion was assessed by analysis of the $\mathrm{Ca}^{2+}$ and $\mathrm{Cl}^{-}$concentrations in the outflow solutions over time (Figure 5). Concentrations were expressed in meq/L in order to visualize the balance between positive and negative charges. The breakthrough of $\mathrm{Cl}^{-}$in the base outflow occurred much earlier than for $\mathrm{Ca}^{2+}$. The transport of $\mathrm{Ca}^{2+}$ was, therefore, retarded compared with $\mathrm{Cl}^{-}$. Adsorption of $\mathrm{Ca}^{2+}$ occurred as a result of exchange with $\mathrm{Na}^{+}$, the major exchangeable cation of MSB (Table 1), as confirmed by measurement of $\mathrm{Na}^{+}$concentrations in the outflow solutions. The dashed lines (Figure 5) represent the sum of $\mathrm{Na}^{+}$and $\mathrm{Ca}^{2+}$ equivalents in the outflow solutions. The lines tend to approach those representing $\mathrm{Cl}^{-}$, in accordance with the requirement for electroneutrality of solutions.

During the transient phase of the test, both $\mathrm{Na}^{+}$and $\mathrm{Ca}^{2+}$ ions diffused downwards together with $\mathrm{Cl}^{-}$in order to satisfy the electrical balance. Observe that exchanged $\mathrm{Na}^{+}$also diffused upwards into the top outflow solution. Release of $\mathrm{Na}^{+}$into the clay pore fluid as a result of exchange with $\mathrm{Ca}^{2+}$ created a local $\mathrm{Na}^{+}$concentration gradient between the clay close to the top boundary and the fresh $5 \mathrm{mM} \mathrm{CaCl}_{2}$ solution (which was free from $\mathrm{Na}^{+}$) so that counter-diffusion of $\mathrm{Na}^{+}$occurred in the direction opposite to that of the main chemical gradient (Jugnickel et al., 2004). Despite a certain scatter in the concentration measurements, the steady state for $\mathrm{Ca}^{2+}$ diffusion was apparently achieved.

To evaluate the solute-transport parameters, D (bulk diffusion coefficient) and $\mathrm{R}_{\mathrm{d}}$ (retardation factor), the trends in $Q_{\mathrm{t}} v s$. time were analyzed by the time-lag method (Figure 6a,b). The results of the analysis (Table 2) were obtained for a total porosity $n=0.717$ and specimen height $H=7.4 \mathrm{~mm}$.

The steady-state bulk-diffusion coefficients of $\mathrm{Cl}^{-}$ and $\mathrm{Ca}^{2+}$ were very close, in accordance with the electroneutrality constraint. With $\omega=0$ at steady state, the bulk diffusion coefficients defined by equation 6 coincide with the product of the geometric tortuosity

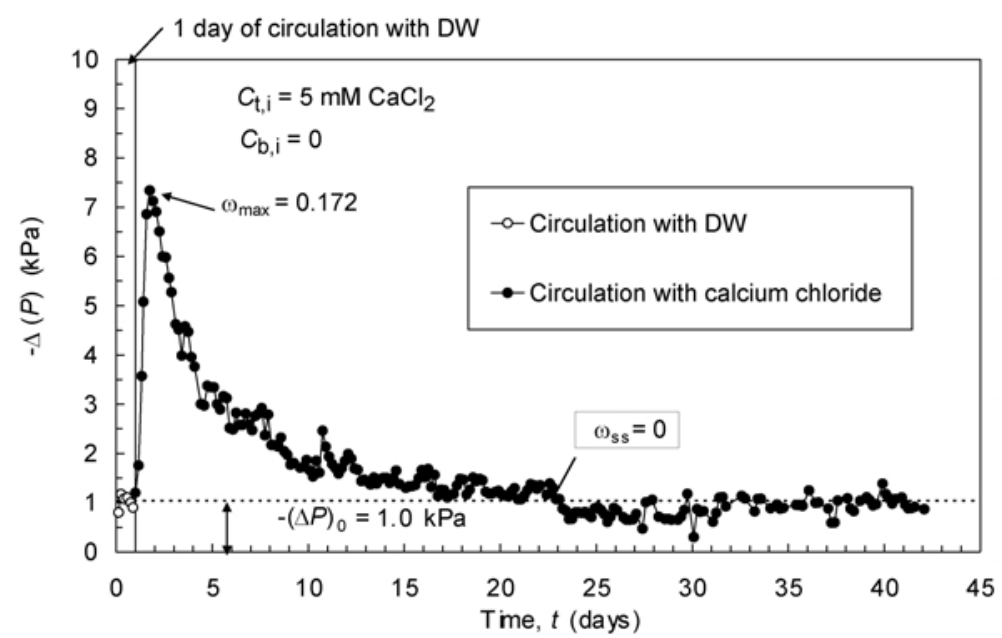

Figure 4. Differential pressure vs. time recorded during the chemico-osmotic stage of the experiment (redrawn after Mazzieri et al., 2005). 


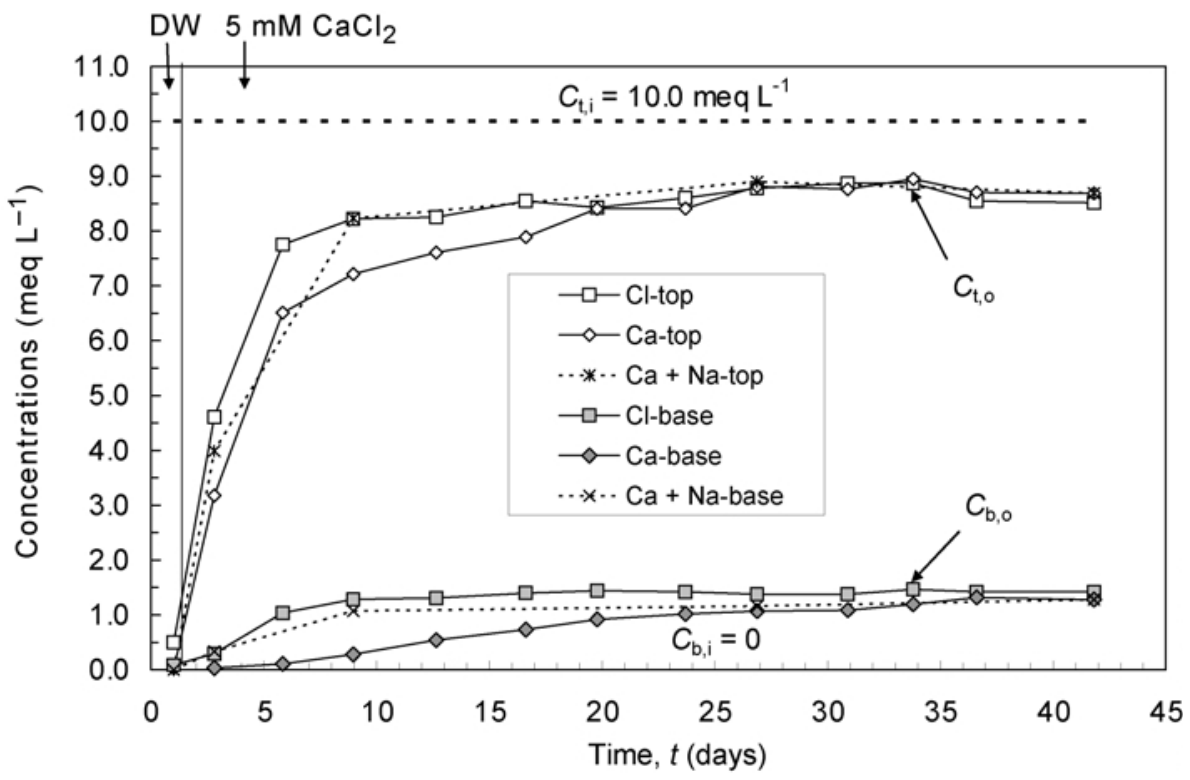

Figure 5. Solute concentrations in the outflow solutions at the top and bottom boundaries of the MSB specimen during the chemicoosmotic/diffusion stage of the experiment (redrawn after Mazzieri et al., 2005).
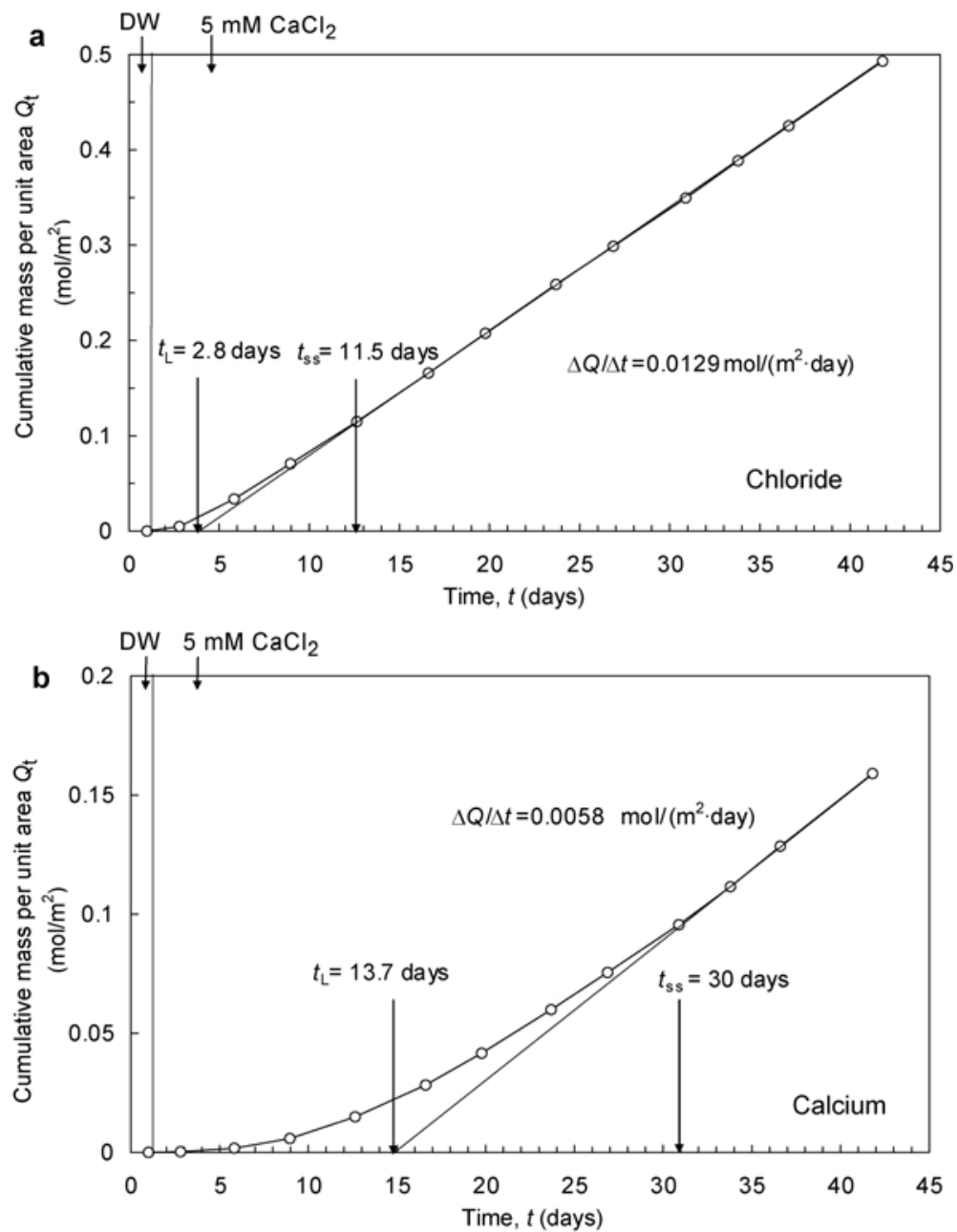

Figure 6. Trends in cumulative mass per unit area $Q_{\mathrm{t}} v$ s. $t$ for $\mathrm{Cl}^{-}$(a) and $\mathrm{Ca}^{2+}(\mathrm{b})$. 
Table 2. Solute transport parameters.

\begin{tabular}{lcccr}
\hline Solute & $\begin{array}{c}\text { Time-lag, } \\
t_{\mathrm{L}}{ }^{\mathrm{a}} \text { (days) }\end{array}$ & $\begin{array}{c}\text { Steady-state, } \\
t_{\mathrm{ss}}{ }^{\mathrm{a}} \text { (days) }\end{array}$ & $\begin{array}{c}D \cdot 10^{10} \\
\left(\mathrm{~m}^{2} / \mathrm{s}\right)\end{array}$ & $\begin{array}{c}R_{\mathrm{d}} \\
(-)\end{array}$ \\
\hline $\mathrm{Cl}^{-}$ & 2.8 & 11.5 & 1.79 & 4.6 \\
$\mathrm{Ca}^{2+}$ & 13.7 & 30.0 & 1.60 & 17.5 \\
& & & & \\
\hline
\end{tabular}

${ }^{\mathrm{a}} 1$ day of circulation with DW has been deducted.

factor and the free diffusion coefficient, often referred to as the effective diffusion coefficient $\left(D^{*}\right)$ in the geotechnical literature (e.g. Shackelford and Daniel, 2001; Malusis et al., 2001). The values of bulk-diffusion coefficients compare well with published data regarding the effective diffusion coefficients of $\mathrm{Ca}^{2+}$ and $\mathrm{Cl}^{-}$in untreated bentonite at similar porosities (Shackelford and Lee, 2003).

The steady-state diffusion of $\mathrm{Cl}^{-}$based on time-lag analysis occurred much earlier (11.5 days) than for $\mathrm{Ca}^{2+}$ (30 days). Based on the calculated $\mathrm{R}_{\mathrm{d}}$ values, both $\mathrm{Cl}^{-}$ and $\mathrm{Ca}^{2+}$ were retarded $\left(\mathrm{R}_{\mathrm{d}}>1\right)$. Firstly, the calculated $\mathrm{R}_{\mathrm{d}}$ value may depend upon the adopted interpretation of the transient phase of the test. The time-lag method fails to take into account electrostatic interactions between ions and assumes that the boundary concentrations are maintained constant throughout the test, whereas the boundary concentrations changed during the test as a result of diffusion (Figure 5).

Release of $\mathrm{Na}^{+}$cations during diffusion of $\mathrm{Ca}^{2+}$ suggested that cation exchange onto the clay surface was the main retarding process for $\mathrm{Ca}^{2+}$. The chemicoosmotic effect and the electrostatic interaction among the diffusing ions also had a role in the transient transport of $\mathrm{Ca}^{2+} \cdot \mathrm{Cl}^{-}$is usually considered a con- servative tracer in clay diffusion studies since it tends to be repelled from negatively charged surfaces. Theoretically, a conservative tracer should have $\mathrm{R}_{\mathrm{d}}=1$. Besides solute restriction $(\omega>0)$, the retardation of $\mathrm{Cl}^{-}$could be partly explained by the counter-diffusion of $\mathrm{Na}^{+}$into the top solution, which may have delayed the downward diffusion of $\mathrm{Cl}^{-}$due to the electrical interaction.

\section{Permeation with calcium chloride}

After completion of the chemico-osmotic stage of the test, the MSB specimen was permeated with the $5 \mathrm{mM}$ $\mathrm{CaCl}_{2}$ solution from the top downwards, i.e. in the same direction as the chemical gradient imposed. The hydraulic conductivity of MSB with the electrolyte solution and the $E C$ of the effluent were monitored (Figure 7). For the sake of comparison, the hydraulic conductivity and $E C$ during permeation with DW and the $E C$ of the outflow solution during the chemico-osmotic/ diffusion stage of the test are also displayed. While still very small, the hydraulic conductivity with $5 \mathrm{mM} \mathrm{CaCl}_{2}$ showed an increase to $\sim 7.0 \times 10^{-11} \mathrm{~m} / \mathrm{s}$ compared to $1.1 \times 10^{-11} \mathrm{~m} / \mathrm{s}$ obtained with DW. Thereafter, the $k$ value remained approximately constant, with the $E C$ of the effluent gradually approaching the $E C$ value of the influent solution, suggesting complete replacement of the pore fluid. The piston remained blocked during permeation, so that no additional swelling could occur. In principle, shrinkage of the specimen was not impeded and, therefore, the clay might have detached from the cell walls resulting in sidewall leakage. The evidence at the end of the test seemed to rule out this possibility, however.

Firstly, extracting the clay from the cell was rather difficult, suggesting that a certain pressure was exerted

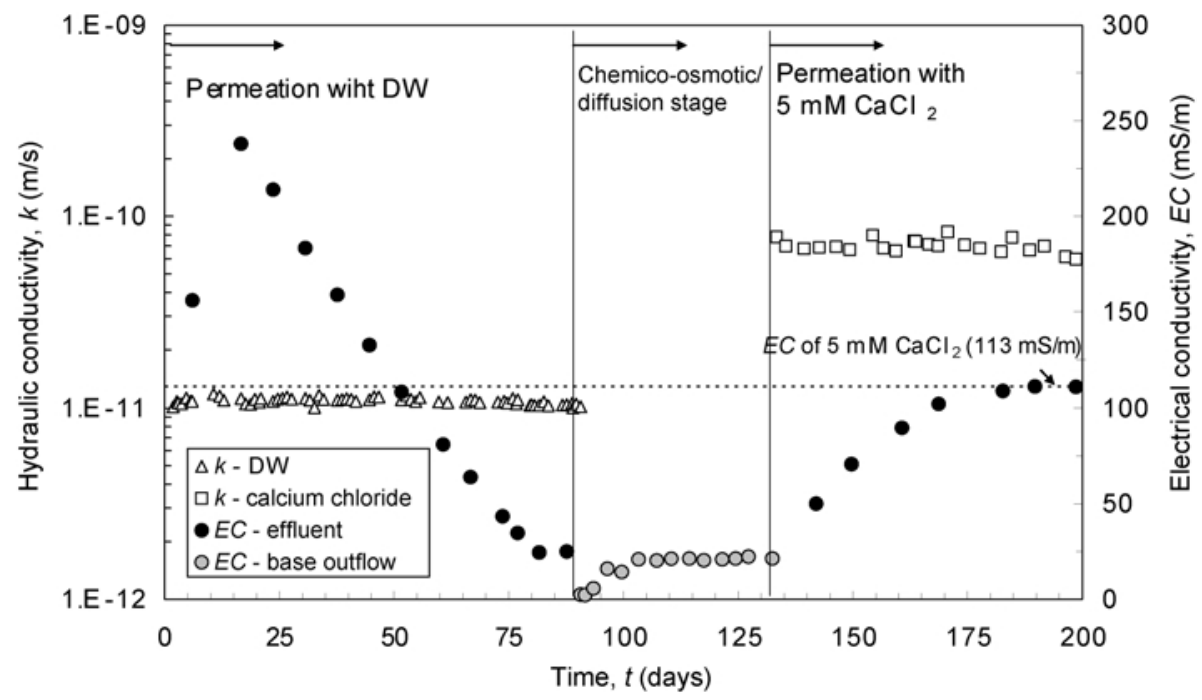

Figure 7. Hydraulic conductivity of MSB vs. $t$ during permeation with DW and with $5 \mathrm{mM} \mathrm{CaCl}_{2}$ solution and $E C$ of the effluent solutions. 
against the walls. Some bentonite solids even remained attached to the cell. Secondly, sidewall leakage would probably have resulted in much greater hydraulic conductivity. In brief, the increase in hydraulic conductivity was related to physicochemical changes induced in the MSB bentonite by the salt solution.

\section{DISCUSSION}

The results obtained in this study qualitatively resemble previous findings by Shackelford and Lee (2003) on untreated bentonite (GCL). Those authors observed a variable osmotic efficiency exhibiting a peak value, followed by a gradual decrease to zero. They concluded that the time required to destroy the membrane behavior correlated almost exactly with the time required to reach steady-state diffusive transport of $\mathrm{Ca}^{2+}$ ions through the GCL specimen, and attributed the destruction of chemico-osmotic behavior to the compression of diffuse double layers, caused by increasing concentrations of divalent $\mathrm{Ca}^{2+}$ in the pore fluid. The results are also in accordance with Bresler (1973) who showed theoretically that the osmotic efficiency decreases with increasing concentration and increasing cation valence. As mentioned earlier, the estimated time required for the destruction of chemico-osmotic behavior of MSB in this study was 22 days, whereas the steady-state diffusion of $\mathrm{Ca}^{2+}$ was reached after 30 days. The scatter in the measurement of the differential pressure may, however, have precluded the exact assessment of the steady state. Although the correlation with steady-state diffusion was less evident than in the study carried out by Shackleford and Lee (2003), the diffusion of $\mathrm{Ca}^{2+}$ cations and the consequent change in clay fabric was probably the main factor responsible for the destruction of chemico-osmotic behavior of MSB.

Test results can be interpreted considering that montmorillonites are organized in quasicrystals (Aylmore and Quirk, 1971), each consisting of several individual layers stacked together. Laird (2006) pointed out that crystalline swelling is a process that occurs within quasicrystals, whereas double-layer swelling occurs between quasicrystals. At the clay/water ratio achieved by the clay during the test, quasicrystals will likely not exfoliate completely. The structure of the hydrated bentonite will consist of a mixture of particle aggregates and individual particles, where double layers extend into voids between quasicrystals and around delaminated individual particles, which reorganize to form soft gels in the open voids (Pusch and Weston, 2003; Guyonnet et al. 2005). In such a structure, most of the water is bound and the hydraulic conductivity to water is typically very low (Mesri and Olson, 1971; Mitchell, 1993; Jo et al., 2001, 2004).

The restriction of ions is greatest when the double layers of adjacent particles overlap in the pore space, leaving little or no free solution for ion transport
(Shackelford and Malusis, 2002). A variation of double-layer thickness and related electrical potentials in the pore space will, therefore, generally influence both the pore space available to solvent flow (i.e. the hydraulic conductivity) and the fraction of pore space available to ions and solvent flow (i.e. the osmotic efficiency). At constant total porosity, compression of the double layers due to the exchange of $\mathrm{Ca}^{2+}$ for $\mathrm{Na}^{+}$ results in an increase in the fraction of pore space available to water transport and a reduction of the pore space restricted to ions. Hence, the increase in permeability is consistent with the observed decrease in chemico-osmotic efficiency (Wintwhorth and Fritz, 1994; Malusis and Shackelford, 2001).

The results suggested that a modification of the initial properties conferred by PC occurred during the test. According to Onikata et al. (1999), PC is bound to the bentonite by coordination with the adsorbed cations in the interlayer of montmorillonite. As the exchange of $\mathrm{Ca}^{2+}$ for $\mathrm{Na}^{+}$cations was demonstrated, the question arises as to whether the exchangeable $\mathrm{Na}^{+}$was removed together with the coordinated PC clouds. Direct assessment of the release of either $\mathrm{PC}$ in the effluent solutions or the presence of PC in the MSB at the end of the test was not possible. Comparison of the dry mass of the specimen before and after the test revealed a mass loss of $\sim 2.00 \mathrm{~g}$, which can be partly attributed to the solids which remained attached to the cell and to the removal of PC during permeation and/or oven-drying. Considering the initial, nominal content of $\mathrm{PC}$ in MSB (20\%), a calculation showed that $3.56 \mathrm{~g}$ of PC was initially bound in the specimen. Even if the mass loss of $2.00 \mathrm{~g}$ was entirely attributed to PC, $1.56 \mathrm{~g}$ of PC would remain bound to the clay.

Free swell tests were performed on the MSB retrieved from the specimen: the free swell was $11 \mathrm{~mL}$ in $\mathrm{DW}$ and $10 \mathrm{~mL}$ in $5 \mathrm{mM} \mathrm{CaCl}_{2}$. These values were significantly different from the results obtained on unused MSB (23 $\mathrm{mL}$ in $\mathrm{DW}$ and $50 \mathrm{~mL}$ in $5 \mathrm{mM} \mathrm{CaCl}_{2}$ ) and were close to values commonly obtained with $\mathrm{Ca}$-bentonites (Egloffstein, 2001). In short, at the end of the test, the MSB appeared to have converted into a Ca-exchanged bentonite partially or totally deprived of PC and of the swelling properties initially conferred by PC. Conversion into a $\mathrm{Ca}$-bentonite probably occurred during the diffusion stage and partly during permeation with $5 \mathrm{mM} \mathrm{CaCl}_{2}$.

Katsumi et al. (2008) performed permeability tests on granular MSB with deionized water with and $\mathrm{CaCl}_{2}$ solutions ranging from $0.1 \mathrm{M}$ to $0.5 \mathrm{M}$. Permeation was carried out at effective stress of $20-30 \mathrm{kPa}$ and for test duration of up to 2 years. For deionized water, $k=$ $1.5 \times 10^{-11} \mathrm{~m} / \mathrm{s}$ was found, very close to the value $k=$ $1.0 \times 10^{-11} \mathrm{~m} / \mathrm{s}$ obtained in the present study using DW. Katsume et al. (2006) obtained $k=6.2 \times 10^{-11} \mathrm{~m} / \mathrm{s}$ with $0.1 \mathrm{M} \mathrm{CaCl}_{2}$, however, and $k=6.5 \times 10^{-11} \mathrm{~m} / \mathrm{s}$ with $0.5 \mathrm{M} \mathrm{CaCl}_{2}$ as opposed to $k=7 \times 10^{-11} \mathrm{~m} / \mathrm{s}$ with 
$5 \mathrm{mM} \mathrm{CaCl}_{2}$ found in the present study. In short, they found a similar permeability of MSB with significantly greater calcium concentrations. Several possible reasons for the difference exist. Firstly, a dry mass of solids per unit area of $0.80 \mathrm{~g} / \mathrm{cm}^{2}$ was used by those authors to prepare the specimens $v s .0 .45 \mathrm{~g} / \mathrm{cm}^{2}$ used in the present study. Secondly, the use of flexible-wall permeameters as opposed to the rigid-wall testing cell and fixed specimen height used in this study may be significant. Finally, in the present study, the MSB was prehydrated and permeated with DW prior to exposure and permeation with the $\mathrm{CaCl}_{2}$ solution, whereas the $\mathrm{MSB}$ was permeated directly with the solutions in the Katsumi et al. (2008) study. In accordance with the molecular model of PC-montmorillonite complexes suggested by Onikata et al. (1999), swelling of MSB occurs as water molecules are attracted inside the PC clouds that surround the interlayer cations. During the initial hydration phase, the MSB specimen was allowed to swell freely with DW. Several molecular layers of water were attracted around the interlayer cations, which could have weakened the intermolecular bond between PC and interlayer cations, so that the PC could eventually have been released. Permeation with DW to wash out soluble salts may also have facilitated elution of PC from the clay. Mazzieri and Pasqualini (2006) observed that MSB permeated directly with natural seawater had a hydraulic conductivity of $5 \times 10^{-11} \mathrm{~m} / \mathrm{s}$, whereas MSB prehydated with DW and then permeated with natural seawater had a hydraulic conductivity of $1.5 \times 10^{-10} \mathrm{~m} / \mathrm{s}$; which contrasts with the behavior of both untreated (Shackelford et al., 2000) and polymer-treated bentonites (Ashmawy et al., 2002), for which prehydration usually produces lower permeability than direct contact with a given solution. Further investigations are necessary to clarify the effect of prehydration on the hydraulic performance of MSB in the presence of a potentially aggressive solution.

\section{CONCLUSIONS}

A combined chemico/osmotic diffusion test was carried out in order to investigate solute diffusion and to evaluate the potential for membrane behavior of a chemically modified bentonite (MSB), obtained by treating base sodium bentonite with propylene carbonate. The chemico-osmotic/diffusion stage of the test was performed using a $5 \mathrm{mM} \mathrm{CaCl} 2$ solution. The diffusion stage was preceded by permeation with distilled water and followed by permeation with the $5 \mathrm{mM} \mathrm{CaCl}_{2}$ solution.

The steady-state solute-diffusion coefficients in MSB were $1.60 \times 10^{-10} \mathrm{~m}^{2} / \mathrm{s}$ for $\mathrm{Ca}^{2+}$ and $1.79 \times 10^{-10} \mathrm{~m}^{2} / \mathrm{s}$ for $\mathrm{Cl}^{-}$, respectively. The values were very close, in accordance with the requirement for electroneutrality, and compared well with values commonly described for untreated bentonites under similar conditions. The MSB exhibited a time-dependent membrane behavior, with a peak osmotic efficiency $\omega$ of 0.172 followed by a gradual reduction to $\omega=0$. The reduction of osmotic efficiency was associated with the breakthrough of $\mathrm{Ca}^{2+}$ cations through the specimen and the release of $\mathrm{Na}^{+}$ cations. The hydraulic conductivity increased from $1.1 \times 10^{-11} \mathrm{~m} / \mathrm{s}$ in DW to $7.0 \times 10^{-11} \mathrm{~m} / \mathrm{s}$ in $5 \mathrm{mM}$ $\mathrm{CaCl}_{2}$. The increase in hydraulic conductivity was also attributed to the invasion of pore space by $\mathrm{Ca}^{2+}$ cations.

Although direct evidence of the concomitant release of the organic additive during the test was not provided in this study, the final properties of the MSB (free swell, hydraulic conductivity) were consistent with those of an untreated and calcium-exchanged bentonite. Prehydration and subsequent permeation water might have contributed to elution of the organic additive from the clay. More research is warranted to extend the results of this study to different solutes, different porosities, and to different testing methods. In particular, further investigations are necessary to clarify the effect of prehydration on the hydraulic performance of MSB in the presence of potentially aggressive permeants.

\section{LIST OF ABBREVIATIONS}

$$
\begin{aligned}
& \mathrm{GCL}=\text { geosynthetic clay liner } \\
& \mathrm{MSB}=\text { multiswellable bentonite } \\
& \mathrm{NB}=\text { base (untreated) bentonite } \\
& \mathrm{PC}=\text { propylene carbonate } \\
& \mathrm{CEC}=\text { cation exchange capacity } \\
& \mathrm{DW}=\text { distilled water } \\
& E C=\text { electrical conductivity }
\end{aligned}
$$

\section{ACKNOWLEDGMENTS}

Financial support to the research program was provided by Ghent University through GOA grant 12.058.598. The tests described in this paper are part of the doctoral thesis of Mrs Gemmina di Emidio. The authors are grateful to Dr. M. Onikata of Hojun Kogyo Corp., Japan, for supplying the bentonite materials used in this study and for the useful discussions.

\section{REFERENCES}

Ashmawy, A.K., El-Hajji, D., Sotelo, N., and Naim, M. (2002) Hydraulic performance of polymer-treated bentonite in inorganic landfill leachates. Clays and Clay Minerals, 50, 546-553.

Aylmore, L.A.G. and Quirk, J.P. (1971) Domains and quasicrystalline regions in clay systems. Soil Science Society of America Journal, 35, 652-654.

Bolt, G.H. (1956) Physico-chemical analysis of the compressibility of pure clays. Géotechnique, 6, 86-93.

Bouazza, A. (2002) Geosynthetic Clay Liners. Geotextiles and Geomembranes, 20, 3-17.

Bresler, E. (1973) Anion exclusion and coupling effects in nonsteady transport through unsaturated soil: I. Theory. Soil Science Society of America Journal, 37, 663-669.

Crank, J. (1975) The Mathematics of Diffusion ( $2^{\text {nd }}$ edition). Clarendon Press, Oxford, UK, 414 pp.

Egloffstein, T.A. (2001) Natural bentonites: influence of the 
ion exchange and partial desiccation on permeability and self-healing capacity of bentonites used in GCLs. Geotextiles and Geomembranes, 19, 427-444.

Fritz, J. (1986) Ideality of clay membranes in osmotic processes: A review. Clays and Clay Minerals, 34, $214-223$.

Guyonnet, D., Gaucher, E., Gaboriau, H., Pons, C.-H., Norotte, V., and Didier, G. (2005) Geosynthetic clay liner interaction with leachate: correlation between permeability, microstructure, and surface chemistry. Journal of Geotechnical and Geoenvironmental Engineering, 131, 740-749.

Jo, H.Y., Katsumi, T., Benson, C.H., and Edil, T.B. (2001) Hydraulic conductivity and swelling of non-prehydrated GCLs permeated with single species salt solutions. Journal of Geotechnical and Geoenvironmental Engineering, 127, $557-567$.

Jo, H.Y., Katsumi, T., Benson, C.H., and Edil, T.B. (2004) Hydraulic conductivity and cation exchange in non-prehydrated and pre-hydrated bentonite permeated with weak inorganic solutions. Clays and Clay Minerals, 52, 661-679.

Jugnickel, C., Smith, D., and Fityus, S. (2004) Coupled multiion electrodiffusion analysis for clay soil. Canadian Geotechnical Journal, 41, 287-298.

Katchalsky A. and Curran, P.F. (1965) Nonequilibrium Thermodynamics in Biophysics. Harvard University Press, Cambridge, Massachusetts, USA, 248 pp..

Katsumi, T., Onikata, M., Hasegawa, S., Lin, L., Kondo, M., and Kamon, M. (2001) Chemical compatibility of modified bentonite permeated with inorganic solutions. Pp. 419-424 in: Geoenvironmental Engineering, Geoenvironmental Impact Management (R.N. Yong and H.R. Thomas, editors). Thomas Telford, London.

Katsumi, T., Ishimori, H., Onikata, M., and Fukagawa, R. (2008) Long-term barrier performance of modified bentonite materials against sodium and calcium permeant solutions. Geotextiles and Geomembranes, 26, 14-30.

Kijzer, Th., Kleingeld, P.J., and Loch, J.P.G. (1999) Chemical osmosis in compacted clayey material and the prediction of water transport. Engineering Geology, 53, 151-159.

Kolstad, D.C., Benson, C.H., Edil, T.B., and Jo, H.Y. (2004) Hydraulic conductivity of a dense prehydrated GCL permeated with aggressive inorganic solutions, Geosynthetics International, 11, 233-241.

Laird, D.A. (2006) Influence of layer charge on swelling of smectites. Applied clay science, 34, 74-87.

Lo, I.M.C., Mak, R.K.M., and Lee., S.C.H. (1997) Modified clays for waste containment and pollutant attenuation. Journal of Environmental Engineering, 123, 25-32.

Malusis M. and Shackelford, C.D. (2001) Chemico-osmotic efficiency of a geosynthetic clay liner. Journal of Geotechnical and Geoenvironmental Engineering, 128, 97-106.

Malusis, M. and Shackelford, C.D. (2002) Theory for reactive solute transport through clay membrane barriers. Journal of Contaminant Hydrology, 59, 291-316.

Malusis, M.A., Shackelford, C.D. and Olsen, H.W. (2001) A laboratory apparatus to measure the chemico-osmotic efficiency for clay soils. Geotechnical Testing Journal, 24, 229-242

Manassero, M. and Dominijanni, A. (2003) Modelling the osmosis effect on solute migration through porous media. Géotechnique, 53, 481-492.

Mazzieri, F. and Pasqualini, E. (2006) Evaluating the permeability of an organically modified bentonite to natural seawater. Pp. 749-756 in: Proceedings of the $I V^{\text {th }}$ International Conference on Environmental Geotechnics, Cardiff (H.R. Thomas editor). Thomas Telford,

Mazzieri, F., Van Impe, P.O, Van Impe, W.F., and Constales, D. (2003) Measurement of chemico-osmotic parameters of clayey soils. Proceedings XIII ${ }^{\text {th }}$ European Conference ISSMGE, Prague (I. Vaniceck et al. editors) Czech Geotechnical Society CICE, pp. 433-438.

Mesri, G. and Olson, R.E. (1971) Mechanisms controlling the permeability of clays. Clays and Clay Minerals, 19, $151-158$.

Mitchell, J.K. (1993) Fundamentals of Soil Behaviour $\left(2^{\text {nd }}\right.$ edition).Wiley, NY, $437 \mathrm{pp}$.

Mishra, A.K., Ohtsubo, M., Li, L., and Higashi, T. (2006) Effect of salt concentrations on the hydraulic conductivity of the mixtures of basalt soil and various bentonites. Journal of Agricultural Faculty, Kyushu University, Japan, 51, $37-43$.

Norrish, K. and Quirk, J.P. (1954) Crystalline swelling of montmorillonite. Use of electrolytes to control swelling. Nature, 173, 255-256.

Onikata M., Kondo M., and Kamon, M. (1996) Development and characterization of a multiswellable bentonite. Proceedings of the $2^{\text {nd }}$ International Conference on Environmental Geotechnics (M. Kamon, editor). Balkema, Rotterdam, pp. 587-590.

Onikata, M., Kondo, M., Hayashi, N., and Yamanaka, S. (1999) Complex formation of cation-exchanged montmorillonites with propylene carbonate: Osmotic swelling in aqueous electrolyte solutions. Clays and Clay Minerals, 47,672-677.

Onikata M., Fujita K., Kondo M., and Yamanaka, S. (2000) Complex formation of homoionic montmorillonite with propylene carbonate and osmotic swelling in aqueous electrolyte solutions. Molecular Crystals and Liquid Crystals, 341, 345-350.

Pusch, R. and Weston, R. (2003) Microstructural stability controls the hydraulic conductivity of smectitic buffer clay. Applied Clay Science, 23, 35-41.

Quirk, J.P. and Marčelja, S. (1997) Application of doublelayers theories to extensive crystalline swelling of Limontmorillonite. Langmuir, 13, 6241-6248.

Rhoades, J.D. (1996) Salinity: electrical conductivity and total dissolved solids. Pp. 417-435 in: Method of Soil Analysis Part 3 (D.L. Sparks, editor). SSSA, Madison, Wisconsin, USA.

Shackelford, C.D. (2005) Environmental issues in geoenvironmental engineering. Proceedings XVI International Conference ISSMGE, Osaka. Millpress, The Netherlands, pp. $95-122$.

Shackelford, C.D. and Daniel, D.E. (1991) Diffusion in saturated soils, I: Background. Journal of Geotechnical Engineering, 117, 467-484.

Shackelford, C.D. and Lee, J. (2003) The destructive role of diffusion on clay membrane behavior. Clays and Clay Minerals, 51, 186-196.

Shackelford, C.D. and Malusis, M.A. (2002) Clay membrane behavior and coupled solute diffusion. Pp. 289-297 in: Chemo-Mechanical Coupling in Clays; from a Nano-Scale to Engineering Applications (C. Di Maio et al., editors). Swets \& Zeitliger Publishers, The Netherlands.

Shackelford, C.D., Benson, C.H., Katsumi, T., Edil, T.B., and Lin, L. (2000) Evaluating the hydraulic conductivity of GCLs permeated with nonstandard liquids. Geotextiles and Geomembranes, 18, 133-161.

Sumner, M.E. and Miller, W.P. (1996) Cation exchange capacity and exchange coefficients. Pp. 1201-1229 in: Methods of Soil Analysis Part 3 (D.L. Sparks, editor). Soil Science Society of America, Madison, Wisconsin, USA.

Van Impe, P.O, Van Impe, W.F., and Mazzieri, F. (2005) Impact of osmotic efficiency on contaminant transport parameters. Proceedings XVIth International Conference ISSMGE, Osaka. Millpress, The Netherlands, pp. $2343-2346$. 
Viani, B.V., Low, P.F., and Roth, C.B. (1983) Direct measurement of the relation between interlayer force and interlayer distance in the swelling of montmorillonite. Journal of Colloid and Interface Science, 96, 229-244.

Winthworth, T.M. and Fritz, S.J. (1994) Electrolyte-induced solute permeability effects in compacted smectite membranes. Applied Geochemistry, 9, 533-546.

(Received xxxxx 2009; revised xxxxx 2009; Ms. Xxx; A.E. J. Bloggs) 